Collection: IUFRO RG 7.01 2010 - Antalya (Turkey)

"Adaptation of Forest Ecosystems to Air Pollution and Climate Change"

Guest Editors: Elena Paoletti, Yusuf Serengil

\section{Population genetic structure of Platanus orientalis L. in Bulgaria}

\section{Grueva M, Zhelev P}

This paper reports the results of a genetic survey on population structure of Platanus orientalis L. in Bulgaria. Nine populations from southern Bulgaria were investigated by using isozyme gene markers. Nine of the enzyme systems were polymorphic. The populations revealed minor polymorphism, which indicates that the predominant allele was the same for all populations and its frequencies were higher than 0.5. The average number of alleles varied from 2.2 to 2.3, and the effective number of alleles ranged from 1.294 to 1.406 . The percent of polymorphic loci ranged from $53.8 \%$ to $76.9 \%$. Heterozygosity in the populations (average: 0.242 ; range: $0.229-0.289$ ) was higher than the mean values reported for broad-leaved species $(0.183)$. The expected and observed heterozygosities had similar values. The results showed that genetic diversity among populations measured by $F_{S T}(0.077)$ and genetic distances (mean 0.029 ) was within the range of the values for Angiosperm tree species. The information could be used for designing proper gene conservation strategies.

Keywords: Platanus orientalis, Population structure, Conservation

\section{Introduction}

Eastern plane (Platanus orientalis L.) occurs in Europe only in the eastern part of Mediterranean region, including some remnants in Calabria and Sicily (southern Italy Tutin 1964). Its natural range spreads eastward through Caucasus and Asia Minor to Iran (Mossadegh 1979, Panetsos 1984). P. orientalis is a fast growing species having both economical and ornamental importance. A limitation for a wider cultivation of the species in Europe is its frost sensitivity and therefore in the other parts of central and western Europe hybrid plane (London plane, Platanus $\times$ acerifolia Willd.) is preferred (Santamour 1970, Panetsos et al. 1994).

In Bulgaria $P$. orientalis appears southwards of the $42^{\text {nd }}$ latitudinal parallel and occupies mainly river banks. In contrast to other riparian species, it is very tolerant to

$\square$ University of Forestry, 10 Kliment Ohridsky Blvd., BG-1756 Sofia (Bulgaria)

\section{@ Mira Grueva (mirageorgieva@abv.bg)}

Received: May 04, 2011 - Accepted: May 19, 2011

Citation: Grueva M, Zhelev P, 2011. Population genetic structure of Platanus orientalis L. in Bulgaria. iForest 4: 186-189 [online 2011-08-11] URL:

http://www.sisef.it/iforest/show.php? id $=580$ soil conditions and can grow on very limited soil layers and on gravel along the rivers, thus depending mostly on soil humidity. Even though it is rather abundant along the rivers in the southern part of the Balkan peninsula and in the Aegean islands, the species is considered rare in Bulgaria and was included in the Red Data Book of Bulgaria (Velcev 1984). The habitats of $P$. orientalis (Palaearctic code 44.711) are included in the Appendix 1 of the resolution no. 4/1996 of the Permanent Committee of the Bern convention. Therefore, this species requires measures for conservation and sustainable management.

Populations of this species in Bulgaria are located in three regions over four river basins. Since river basins are separated by relatively high mountain ridges and some of the populations are also rather distant geographically, it is of particular interest to study the genetic variation and the differentiation between and within populations of $P$. orientalis. Both biochemical and morphological quantitative markers could be useful for such a study, since the molecular markers and quantitative traits tend to express different levels and patterns of variation. Although the use of both types of traits for population structure and differentiation studies is controversial (Lewontin 1984, Felsenstein 1986), there are some examples of successful application of such an approach (Lascoux et al. 1996).

The objective of the present study was to assess the genetic variation and population structure of Platanus orientalis in Bulgaria, where it reaches the northernmost limit of its natural distribution. The knowledge of the distribution of genetic variation within and among populations could be useful for better understanding the species evolution and for designing gene conservation strategies.

\section{Material and methods}

\section{Plant material}

The material for the study was collected from nine populations, representing the whole area of distribution of the species in Bulgaria (Tab. 1). Fifty to sixty randomly chosen trees per population were sampled. Dormant winter buds, sometimes starting to flush, were used for the analysis.

\section{Isozyme analysis}

Enzymes extraction was done after grinding the bud tissue in Tris- $\mathrm{HCl}$ extraction buffer $\mathrm{pH}$ 7.3. Ten milligrams of Polyvinilpolypyrrholidone (PVPP-40) were added as a stabilizing agent in the plastic vessels, where the extraction took place. Before extraction, $15 \mathrm{mg}$ dithiothreitol (DTT), $500 \mathrm{mg}$ saccharose, $150 \mathrm{mg}$ Polyvinil-pyrrholidone (PVP-40) and $5 \mathrm{mg} \mathrm{Na} \mathrm{Na}_{2}$ EDA were dissolved in $15 \mathrm{ml}$ extraction buffer, and $100 \mu \mathrm{l}$ $\beta$-mercaptoethanol were also added to the solution.

Standard $12 \%$ starch gel electrophoresis was applied to separate the isoenzyme variants, in two buffer systems: Lithium-borate - Tris-citrate $\mathrm{pH} 8.1$ discontinuous buffer system (Ashton \& Braden 1961) and Tris-

Tab. 1 - Bulgarian populations of Platanus orientalis from which samplings were collected.

\begin{tabular}{lcc}
\hline \multicolumn{1}{c}{ Population (abbreviation) } & Geographic coordinates & Altitude (m a.s.l.) \\
\hline Kresna (KR) & $41^{\circ} 44^{\prime} \mathrm{N} 23^{\circ} 08^{\prime} \mathrm{E}$ & 300 \\
Sandanski (SA) & $41^{\circ} 36^{\prime} \mathrm{N} 23^{\circ} 20^{\prime} \mathrm{E}$ & 200 \\
Slavyanka (SL) & $41^{\circ} 26^{\prime} \mathrm{N} 23^{\circ} 33^{\prime} \mathrm{E}$ & 500 \\
Petrich (PE) & $41^{\circ} 24^{\prime} \mathrm{N} 23^{\circ} 03^{\prime} \mathrm{E}$ & 400 \\
Melnik (ME) & $41^{\circ} 30^{\prime} \mathrm{N} 23^{\circ} 24^{\prime} \mathrm{E}$ & 250 \\
Goce Delchev (GD) & $41^{\circ} 37^{\prime} \mathrm{N} 23^{\circ} 52^{\prime} \mathrm{E}$ & 300 \\
Assenovgrad (AS) & $41^{\circ} 58^{\prime} \mathrm{N} 24^{\circ} 52^{\prime} \mathrm{E}$ & 150 \\
Topolovo (TO) & $4^{\circ} 54^{\prime} \mathrm{N} 25^{\circ} 00^{\prime} \mathrm{E}$ & 150 \\
Ivaylovgrad (IV) & $4^{\circ} 35^{\prime} \mathrm{N} 26^{\circ} 06^{\prime} \mathrm{E}$ & 300 \\
\hline
\end{tabular}


Tab. 2 - Investigated enzyme systems. (A): Lithium borate $(\mathrm{pH} 8.1)$ Tris Citrate $(\mathrm{pH} 8.1)$ discontinuous buffer system (Ashton \& Braden 1961). (TC): Tris Citrate (pH 7.0) continuous buffer system (Shaw \& Prasad 1970).

\section{Enzyme system (abbreviation and EC code)}

Glutamate dehydrogenase ( $G D H, 1.4 .1 .2)$

Glutamate-oxaloacetate transaminase (GOT, 2.6.1.1)

Leucine aminopeptidase $(L A P, 3.4 .11 .1)$

Malate dehydrogenase $(M D H, 1.1 .1 .37)$

Menadione reductase $(M N R, 1.6 .99 .2)$

Phosphoglucomutase (PGM, 5.4.2.2)

Phosphpoglucose isomerase (PGI, 5.3.1.9)

Shikimate dehydrogenase $(S k D H, 1.1 .1 .25)$

Alcohol dehydrogenase $(A D H, 1.1 .1 .1)$

Tab. 3 - Characteristics of genetic diversity and polymorphism. $(N)$ : mean number of individuals studied; $\left(N_{\mathrm{a}}\right)$ : mean number of alleles/locus; $\left(N_{\mathrm{e}}\right)$ : effective allele number (harmonic mean); $(P)$ : percent of polymorphic loci ( 0.05 criterion); $\left(H_{\mathrm{o}}\right)$ : observed heterozygosity; $\left(H_{\mathrm{e}}\right)$ : expected heterozygosity; (SE): standard error; $(F)$ : inbreeding coefficient $\left(F=1-H_{\mathrm{o}} / H_{\mathrm{e}}\right)$; $(*)$ : significantly different from zero $(p \leq 0.05)$.

\begin{tabular}{lccccccc}
\hline \multicolumn{1}{c}{ Population } & $\begin{array}{c}\boldsymbol{N} \\
(\mathbf{S E})\end{array}$ & $\begin{array}{c}\boldsymbol{N}_{\mathrm{a}} \\
(\mathbf{S E})\end{array}$ & $\boldsymbol{N}_{\mathrm{e}}$ & $\mathbf{P}$ & $\begin{array}{c}\boldsymbol{H}_{\mathbf{0}} \\
(\mathbf{S E})\end{array}$ & $\begin{array}{c}\boldsymbol{H}_{\mathbf{e}} \\
(\mathbf{S E})\end{array}$ & $\mathbf{F}$ \\
\hline Kresna & 52.7 & 2.3 & 1.314 & 61.5 & 0.239 & 0.237 & -0.008 \\
& $(1.9)$ & $(0.2)$ & & & $(0.072)$ & $(0.059)$ & \\
Sandanski & 49.2 & 2.2 & 1.312 & 61.5 & 0.238 & 0.260 & $0.085^{*}$ \\
& $(1.9)$ & $(0.1)$ & & & $(0.060)$ & $(0.053)$ & \\
Slavyanka & 53.8 & 2.5 & 1.406 & 69.2 & 0.289 & 0.289 & 0.000 \\
& $(2.7)$ & $(0.3)$ & & & $(0.066)$ & $(0.055)$ & \\
Petrich & 56.0 & 2.3 & 1.331 & 61.5 & 0.249 & 0.245 & -0.016 \\
& $(0.5)$ & $(0.2)$ & & & $(0.066)$ & $(0.055)$ & \\
Melnik & 67.5 & 2.2 & 1.297 & 53.8 & 0.229 & 0.229 & 0.000 \\
& $(1.6)$ & $(0.2)$ & & & $\begin{array}{c}0.064) \\
(0.058)\end{array}$ & \\
Goce Delchev & 63.5 & 2.2 & 1.349 & 76.9 & 0.259 & 0.241 & -0.075 \\
& $(0.3)$ & $(0.3)$ & & & $(0.079)$ & $(0.057)$ & \\
Asenovgrad & 38.5 & 2.2 & 1.294 & 61.5 & 0.227 & 0.249 & $0.088^{*}$ \\
& $(1.4)$ & $(0.2)$ & & & $(0.063)$ & $(0.056)$ & \\
Topolovo & 51.3 & 2.3 & 1.295 & 76.9 & 0.228 & 0.283 & $0.194 *$ \\
& $(2.4)$ & $(0.2)$ & & & $(0.070)$ & $(0.053)$ & \\
Ivaylovgrad & 49.6 & 2.2 & 1.337 & 69.2 & 0.252 & 0.242 & -0.041 \\
& $(1.0)$ & $(0.3)$ & & & $(0.069)$ & $(0.055)$ & \\
\hline
\end{tabular}

citrate $\mathrm{pH} 7.0$ continuous buffer system (Shaw \& Prasad 1970). The enzyme systems and loci scored are listed in Tab. 2.

The loci were numbered according to their

Tab. 4 - Shannon index of diversity ( $\left.I^{\prime}\right)$.

\begin{tabular}{lc}
\hline \multicolumn{1}{c}{ Locus } & $\boldsymbol{I}$ \\
\hline Lap-1 & 0.2201 \\
Lap-2 & 0.1930 \\
Got-2 & 1.1594 \\
Gdh & 0.6158 \\
Pgi-1 & 0.2655 \\
Pgi-2 & 0.8955 \\
Mnr & 0.1372 \\
Adh-1 & 0.6392 \\
Adh-2 & 0.6121 \\
Pgm & 0.2390 \\
Mdh & 0.4290 \\
Skdh & 0.3049 \\
Mean & 0.4545 \\
\hline
\end{tabular}

No of loci scored Buffer system

zygosity $\left(H_{\mathrm{o}}\right)$; inbreeding coefficient $F=1$ $H_{\mathrm{o}} / H_{\mathrm{e}}$. The software Biosys-1 (Swofford \& Selander 1989) was used. Shannon index of diversity $\left(I^{\prime}\right)$ was used as an additional criterion. Genetic distances between population pairs were computed according to Nei (1978). The differentiation was tested by means of $F$-statistics (Wright 1965) following the method of Weir \& Cockerham (1984) and using the software Genepor v.3.1c. (Raymond \& Rousset 1995). While $F_{\text {ST }}$ was used to measure differentiation over populations, $F_{\text {IS }}$ and $F_{\text {IT }}$ were used to test the deviation from Hardy-Weinberg expectations within populations and in the total population, respectively. Multidimensional scaling (Principal Coordinate Analysis Gower 1966) was applied for better interpretation of genetic distances by means of the software SYN-TAX (Podani 1993).

\section{Results and discussion}

\section{Polymorphism and diversity}

Nine of the enzyme systems studied were polymorphic - LAP, GOT, GDH, PGI, PGM, MNR, ADH, MDH, and SKDH. The allele frequencies are available from authors upon request. The predominant allele was the same in all populations, which corresponds to the so-called "minor polymorphism" (Lewontin 1985). The polymorphism and diversity parameters (Tab. 3 ) indicate that the level of intrapopulation genetic diversity in Platanus orientalis is well within the range of the figures reported for cross-pollinating, long-lived broadleaved species (Hamrick et al. 1992). The mean allele number per locus varied within the narrow range 2.2 to 2.3 . Maximum number of alleles (5) was found in the Got-2 locus. The effective allele number (or the reciprocal of homozygosity Crow \& Kimura 1970) ranged from 1.294 (Asenovgrad) to 1.406 (Slavyanka). The Shannon's index of diversity, borrowed from the information theory and numerical eco-

position from the anode, i.e., the fastest one was numbered 1 and so forth, and the alleles were numbered according to their relative mobility relative to the most common allele (allele 100).

\section{Data analysis}

Allele frequencies were calculated from diploid genotypes. Genetic diversity within populations was characterized by the following parameters: mean number of alleles $\left(N_{\mathrm{a}}\right)$; effective number of alleles $\left(N_{\mathrm{e}}=1 / \Sigma_{\mathrm{i}}\right.$ $p_{\mathrm{i}}^{2}$, where $p_{\mathrm{i}}$ is the frequency of the $i$-th allele) for a locus and harmonic mean of all loci; percent of polymorphic loci, applying 0.05 criterion, which means that a locus is considered polymorphic if the frequency of the predominant allele does not exceed 0.95; expected heterozygosity $H_{\mathrm{e}}=1-\Sigma_{\mathrm{i}}\left(1-p_{\mathrm{i}}^{2}\right)$, where $p_{\mathrm{i}}$ is the frequency of the $i$-th allele (Nei 1978); observed (direct-count) hetero-
Tab. 5 - F-statistics and putative migration. $(\mathrm{Nm})$ : number of migrants per generation calculated as $N m=0.25\left(1-F_{\text {ST }}\right) / F_{\text {ST }}$.

\begin{tabular}{lcccc}
\hline \multicolumn{1}{c}{ Locus } & $\boldsymbol{F}_{\text {IS }}$ & $\boldsymbol{F}_{\text {IT }}$ & $\boldsymbol{F}_{\text {ST }}$ & $\boldsymbol{N} \boldsymbol{N}$ \\
\hline Lap-1 & 0.306 & 0.324 & 0.026 & 9.1949 \\
Lap-2 & 0.351 & 0.429 & 0.121 & 1.8230 \\
Got-1 & 0.328 & 0.366 & 0.057 & 4.1396 \\
Got-2 & -0.206 & -0.168 & 0.031 & 7.7110 \\
Gdh & -0.161 & -0.059 & 0.088 & 2.5750 \\
Pgi-1 & 0.450 & 0.473 & 0.042 & 5.6915 \\
Pgi-2 & 0.385 & 0.533 & 0.240 & 0.7901 \\
Mnr & 0.379 & 0.388 & 0.015 & 16.6564 \\
Adh-1 & -0.031 & 0.010 & 0.040 & 6.0737 \\
Adh-2 & -0.323 & -0.281 & 0.032 & 7.5851 \\
Pgm & -0.056 & 0.022 & 0.073 & 3.1635 \\
Mdh & 0.140 & 0.168 & 0.032 & 7.4486 \\
Skdh & 0.154 & 0.189 & 0.040 & 5.9241 \\
Mean & 0.019 & 0.094 & 0.077 & 2.9710 \\
\hline
\end{tabular}


logy (Crow 2001) is sometimes used as an additional measure of diversity. The Got-2 locus had the highest value, with the highest allele number (Tab. 4).

The percent of polymorphic loci ranged from 53.8 (Melnik) to $76.9 \%$ (Topolovo 0.05 criterion). These results are somewhat higher than the average values summarized in Hamrick et al. (1992) for tree species $(59.5 \%)$. Both observed and expected heterozygosities were high and the differences between them for the respective populations were low, as indicated by the inbreeding coefficient (Tab. 3). The highest heterozygosity was found in the population of Slavyanka $(0.289)$ and the lowest one was in the population of Melnik (0.229).

\section{Genetic differentiation among popula-} tions

Usually the genetic differentiation is measured by comparing the pairwise genetic distances (Nei 1978) and the average indicator of the differentiation $F_{\mathrm{ST}}$ (or $G_{\mathrm{ST}}$ ). The overall genetic differentiation $\left(F_{\mathrm{ST}}\right)$ was 0.077 (Tab. 5), fairly similar to values summarized by Hamrick et al. (1992) for species with similar life-history characteristics. High level of inbreeding was found at MNR locus, which differed from the remaining loci. The populations were most differentiated at locus Lap-2, which could be due to occurrence of silent alleles, a relatively frequent phenomenon in LAP isozymes, but undetectable when diploid tissue is analyzed.

The putative number of migrants calculated by using the $F_{\mathrm{ST}}$ values varied from 2 to 16 for the different loci $($ mean $=2.97)$. The average number of migrant calculated by the

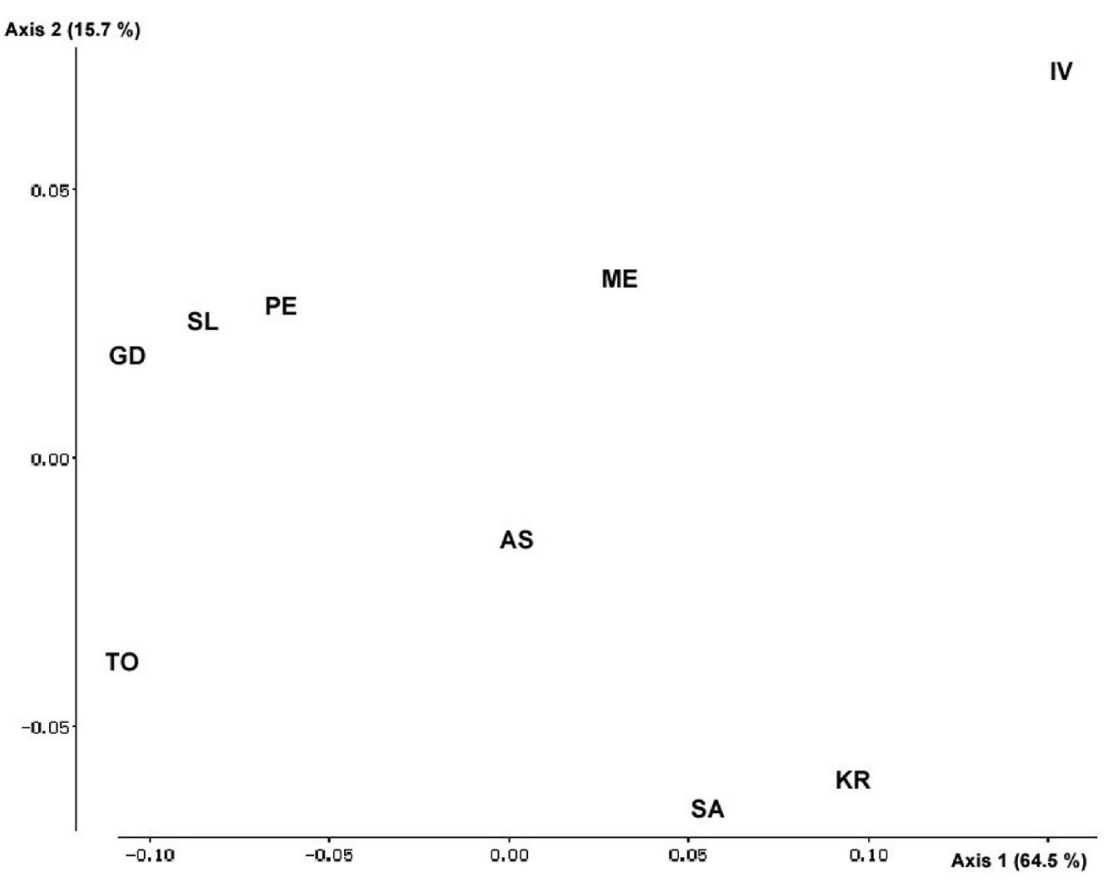

Fig. 1 - Multidimensional scaling of the populations on the basis of the genetic distances. netic drift. fecting this locus.

Tab. 6 - Genetic distances between the population pairs.

\begin{tabular}{lcccccccc}
\hline \multicolumn{1}{c}{ Population } & SA & SL & PE & ME & GD & AS & TO & IV \\
\hline Kresna (KR) & 0.012 & 0.050 & 0.035 & 0.017 & 0.052 & 0.019 & 0.052 & 0.028 \\
Sandanski (SA) & - & 0.034 & 0.033 & 0.014 & 0.042 & 0.012 & 0.040 & 0.033 \\
Slavyanka (SL) & - & - & 0.008 & 0.019 & 0.008 & 0.017 & 0.018 & 0.069 \\
Petrich (PE) & - & - & - & 0.010 & 0.005 & 0.013 & 0.010 & 0.055 \\
Melnik (ME) & - & - & - & - & 0.018 & 0.005 & 0.029 & 0.022 \\
Goce Delchev (GD) & - & - & - & - & - & 0.014 & 0.013 & 0.078 \\
Asenovgrad (AS) & - & - & - & - & - & - & 0.023 & 0.038 \\
Topolovo (TO) & - & - & - & - & - & - & - & 0.085 \\
Ivaylovgrad (IV) & - & - & - & - & - & - & - & - \\
\hline
\end{tabular}

Private allele method (Slatkin \& Barton 1989) was 7.49. The differences could be due to the specific approaches for calculation or to violations of the assumptions, but in both cases this number was below 10 . This fact indicates that there were mechanisms that make the isolation ineffective. This could be due to the light pollen grains of the species, and also to the fact that its fruits could be transported by the water stream at long distances. We hypothesize that even a small number of migrants is sufficient to overpower the differences among populations that could appear solely by ge-

Locus MNR again showed different patterns of variation. It was the least differentiating locus, and with high inbreeding. As its visualization and interpretation was the easiest one, we can exclude possible misinterpretation of the electrophoregram as an explanation; we thus hypothesize that there were some mechanisms of selection most af-

El-Kassaby \& Yanchuk (1995) and David- son \& El-Kassaby (1997) modified the approach used by Slatkin (1985) for assessing the genetic uniqueness of a population by removing it from the dataset and recalculating the overall level of differentiation among remaining populations. The procedure is repeated $n$ times, where $n$ is the number of populations (see the references above for details). Obviously, when a genetically most different population is out of the data set, the overall differentiation will be the lowest of all cases. In our study this population was Ivaylovgrad (results not shown).

The genetic distances were of magnitude 0.005 to 0.085 , and the most different population again appeared to be Ivaylovgrad, which was also the most distant and isolated one (Tab. 6). Ivaylovgrad showed the highest genetic distances toward the other populations, while highest genetic distances among them were 0.078 (Ivaylovgrad - Goce Delchev) and 0.069 (Ivaylovgrad - Slavyanka).

The Multidimensional Scaling (Fig. 1) confirms these patterns of variation and differentiation and clearly shows the outstanding position of Ivaylovgrad, followed by Topolovo, Goce Delchev and Kresna.

The analysis of the genetic variation and population structure of Platanus orientalis in Bulgaria showed a good level of genetic diversity, both within and among populations. This fact facilitates the selection of populations for conservation. Although the decision requires deeper studies and applying different approaches, this study demonstrated the usefulness of genetic information in designing gene conservation strategies.

\section{References}

Ashton GC, Braden AWH (1961). Serum Bglobulin polymorphism in mice. Australian Journal of Biological Sciences 14: 248-253. [online] URL: http://www.publish.csiro.au/?paper= BI9610248

Crow JF, Kimura M (1970). An introduction to population genetics theory. Harper \& Row, New York, USA, pp. 591.

Crow JF (2001). Shannon's brief foray into genetics. Genetics 159 (3): 915-917. [online] URL: http://www.ncbi.nlm.nih.gov/pubmed/11729140 Davidson R, El-Kassaby YA (1997). Genetic di- 
versity and gene conservation of Pacific silver fir (Abies amabilis) on Vancouver Island, British Columbia. Forest Genetics 4 (2): 85-98.

El-Kassaby YA, Yanchuk AD (1995). Genetic variation of Pacific yew in British Columbia and its conservation. In: "Population genetics and genetic conservation of forest trees" (Baradat $\mathrm{P}$ Adams WT, Müller-Starck G eds). SPB Academic Publishing bv, Hague, The Netherland, pp. 227-235.

Felsenstein J (1986). Population differences in quantitative characters and gene frequencies: a comment on the papers by Lewontin and Rogers. American Naturalist 127 (5): 731-732. - doi $10.1086 / 284520$

Gower JC (1966). Some distance properties of latent root and vector methods used in multivariate analysis. Biometrika 53: 325-338. [online] URL: http://biomet.oxfordjournals.org/content/53/34/325.short

Hamrick JL, Godt MJW, Sherman-Broyles SL (1992). Factors influencing levels of genetic diversity in woody plant species. New Forests 6: 95-124. - doi: 10.1007/BF00120641

Lascoux M, Thorsén J, Gullberg U (1996). Population structure of a riparian willow species, Salix viminalis L. Genetical Research 68: 45-54. - doi: 10.1017/S0016672300033875

Lewontin RC (1984). Detecting population differences in quantitative characters as opposed to gene frequencies. American Naturalist 123 (1) 115-124. - doi: 10.1086/284190
Lewontin RC (1985). Population genetics. Annual Review of Genetics 19: 81-102. - doi: 10.1146/ annurev.ge.19.120185.000501

Mossadegh A (1979). Mini-monograph on Platanus orientalis L. in Iran. Technical consultation on fast-growing plantation of broadleaved trees for Mediterranean and temperate zones. FAO-FGB-79-8/2, FAO, Rome, pp. 19

Nei M (1978). Estimation of average heterozygosity and genetic distance from a small number of individuals. Genetics 89 (3): 583-590. [online] URL: http://www.ncbi.nlm.nih.gov/pubmed/17 248844

Panetsos K, Scaltsoyannes A, Alizoti P (1994). Vegetative propagation of Platanus orientalis $\times$ $P$. occidentalis F1 hybrids by stem cuttings. Forest Genetics 1 (3): 125-130.

Panetsos K (1984). Genetics and breeding of the genus Platanus. Reunion AGRIMED, Antibes (France) 29-30 October 1984.

Podani J (1993). SYN-TAX 5.0: Computer programs for multivariate data analysis in ecology and systematics. Abstracta Botanica 17: 289302.

Raymond M, Rousset F (1995). GENEPOP (version 1.2): population genetics software for exact tests and ecumenicism. Journal of Heredity 86 : 248-249. [online] URL: http://jhered.oxfordjournals.org/content/86/3/248.short

Santamour FS (1970). Hybrid vigor in seedlings of re-created London plane. Nature 225: 11591160. - doi: 10.1038/2251159a0
Shaw CR, Prasad R (1970). Starch gel electrophoresis of enzymes - a compilation of recipes. Biochemical Genetics 4: 297-320. - doi: 10.1007/BF00485780

Slatkin M, Barton N (1989). A comparison of three indirect methods for estimating average levels of gene flow. Evolution 43: 1349-1368. doi: $10.2307 / 2409452$

Slatkin M (1985). Rare alleles as indicators of gene flow. Evolution 39: 53-65. - doi: 10.2307/ 2408516

Swofford DL, Selander RB (1989). BIOSYS-1: a computer program for the analysis of allelic variation in population genetics and biochemical systematics. Illinois Nat. Hist. Survey, Illinois, USA, pp. 43.

Tutin TG (1964). Platanaceae. In: "Flora Europaea 1" (Tutin TG et al. eds). Cambridge University Press, Cambridge, UK, pp. 384.

Velcev V (1984). Red data book of Bulgaria 1 plants. Bulgarian Academy of Sciences, Sofia, Bulgaria, pp. 447. [in Bulgarian].

Weir BS, Cockerham CC (1984). Estimating Fstatistics for the analysis of population structure. Evolution 38: 1358-1370. - doi: 10.2307/ 2408641

Wright S (1965). The interpretation of population structure by F-statistics with special regard to systems of mating. Evolution 19: 395-420. - doi: $10.2307 / 2406450$ 